\title{
INTERPRETASI CITRA RADAR (RADIO DETECTION AND RANGING) DOPPLER BMKG (BADAN METEOROLOGI KLIMATOLOGI DAN GEOFISIKA) PEKANBARU DALAM MEMPREDIKSI CURAH HUJAN DI KOTA PEKANBARU
}

\author{
Dini Aprianti, Arysthya Ardhitama, Yulia Fitri \\ Program Studi Fisika, Fakultas MIPA dan Kesehatan \\ Universitas Muhammadiyah Riau
}

ABSTRACT

In a study of Indonesia is located in the geographic equator. Because of the location of Indonesia became the country's tropical climate, which is marked with rainfall almost throughout the year occur with a high enough intensity. The negative impact of high rainfall that flooded, because the volume of water will overflow and uncontrolled. To measure the amount of rainfall in an area used rain gauges infernal surface manual and automatic. However, rain gauges and automatic manual still has the disadvantage that it can not predict what happens next. Radar imagery is one of the modern gauges and able to provide more accurate data. The radar also can detect the intensity of rainfall in bad weather conditions such as rain storms, floods, tornadoes and lightning. So from the description above, rainfall predictions will be verified from the results of the Doppler radar image interpretation with rain gauges located in Pekanbaru BMKG based on observational data were analyzed with a test statiskit MAE test, degree of homogeneity, and the value of the correlation coefficient. Based on the test results Statistics. Such as: MAE test, Correlation Coefficient and Homogeneity Test, the radar is able to predict the rainfall in Pekanbaru correctly.

Key words: Rainfall, Radar, Radar Image, rain gauge, Doppler Radar.

\section{PENDAHULUAN}

Wilayah Indonesia berada di antara Benua Asia dan Australia serta berada diantara Samudera Hindia dan Pasifik. Dalam kajian geografis Indonesia terletak di daerah khatulistiwa. Karena letak tersebut Indonesia menjadi negara yang beriklim tropis, yaitu ditandai dengan curah hujan yang hampir sepanjang tahun terjadi dengan intensitas yang cukup tinggi ${ }^{[1]}$.

Pola curah hujan yang tinggi dan terjadi secara berlebihan serta tidak menentu dapat memberikan dampak negatif. Dampak negatif yang ditimbulkan yaitu banjir, karena volume air akanmelimpah dan tidak terkendalikan. Dan juga bencana kekeringan pada musim kemarau, sehingga padi gagal panen karena air tidak mencukupi. Maka dari itu diperlukan adanya prediksi curah hujan ${ }^{[2,3]}$.

Untuk mengukur jumlah curah hujan pada suatu daerah perrmukaan digunakan alat penakar hujan. Alat penakar hujan memiliki dua macam, yaitu alat penakar hujan manual dan otomatis. Alat penakar hujan manual diamati setiap 3 jam sekali, kelebihan dari alat ini yaitu kita dapat mengamati data setiap saat. Kekurangan dari alat penakar hujan manual yaitu terjadinya kesalahan pada saat pengamatan, sedangkan alat penakar hujan otomatis memiliki kelebihan yaitu kita tidak perlu mengamatinya settiap jam. Namun, alat penakar hujan manual dan otomatis ini masih memiliki kekurangan yaitu tidak dapat memprediksi kejadian selanjutnya ${ }^{[4]}$.

Citra Radar merupakan salah satu alat penakar yang modern dan mampu memberikan data yang lebih akurat. Dibandingkan dengan alat penakar hujan. Radar juga memiliki beberapa kelebihan lain, diantaranya dapat menentukan lokasi terjadinya hujan dan menghitung besar kecepatannya serta menentukan jenisnya (hujan salju, hujan es dan sebagainya). Selain itu, radar juga dapat mendeteksi intensitas curah hujan dalam keadaan cuaca buruk seperti hujan badai, banjir, puting beliung dan petir. Maka dari uraian 
diatas, akan diverifikasi prediksi curah hujan dari hasil interpretasi citra radar Doppler dengan alat penakar hujan yang berada di BMKG Pekanbaru $[5,6]$.

\section{METODOLOGI PENELITIAN}

\section{Alat}

Alat yang digunakan dalam penelitian ini diantaranya yaitu seperangkat komputer untuk melihat data radar. Alat lainnya dalam penelitian ini yaitu penakar hujan (Gambar 1) dan radar Doppler (Gambar 2).

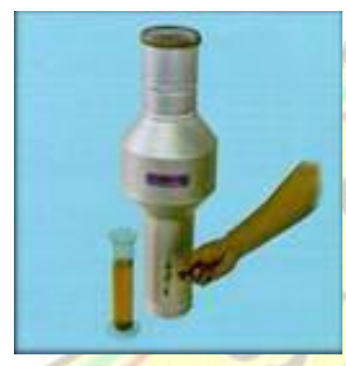

(a)

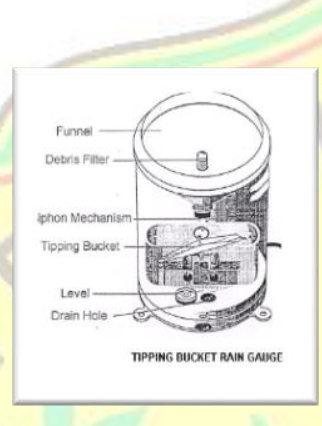

(b)
Gambar.1. (a) Penakar Curah Hujan Manual dan (b) Penakar Curah Hujan Otomatis [5]

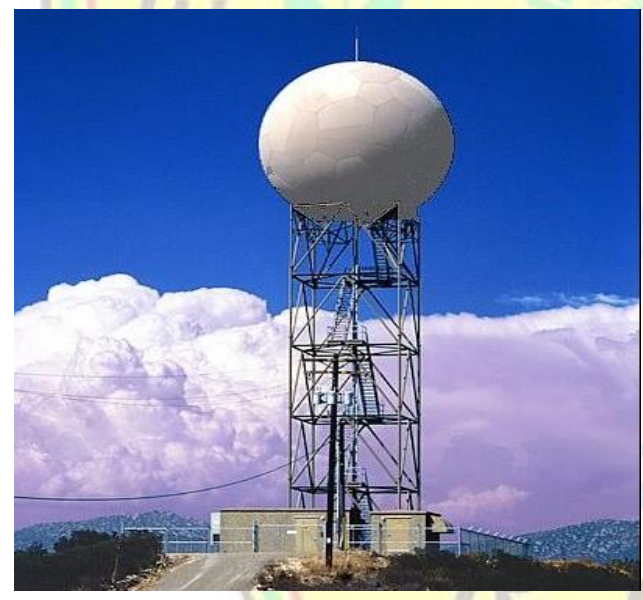

Gambar.2. Radar Doppler[6]

\section{Prosedur Kerja}

Gambar 3 menunjukkan proses pengambilan dan analisa data dalam penelitian ini. Dari gambar tersebut dapat dilihat jika pengambilan data dibagi menjadi 2 bagian, yaitu pengambilan data radar dan data alat penakar.

\section{Pengambilan Data Pada Radar}

Radar akan memancarkan gelombang elektromagnetik yang dibenturkan ke awan yang bergerak, kemudian dibalikkan lagi ke radar dalam variasi warna dengan angka dalam bentuk range, dan radar akan mengirimkan data tersebut pada komputer-komputer yang ada di BMKG Pekanbaru. Data radar berupa data warna yang masing-masing warna memiliki range dan intensitas curah hujan. Berikut Tabel 1 menunjukkan range warna pada data radar.

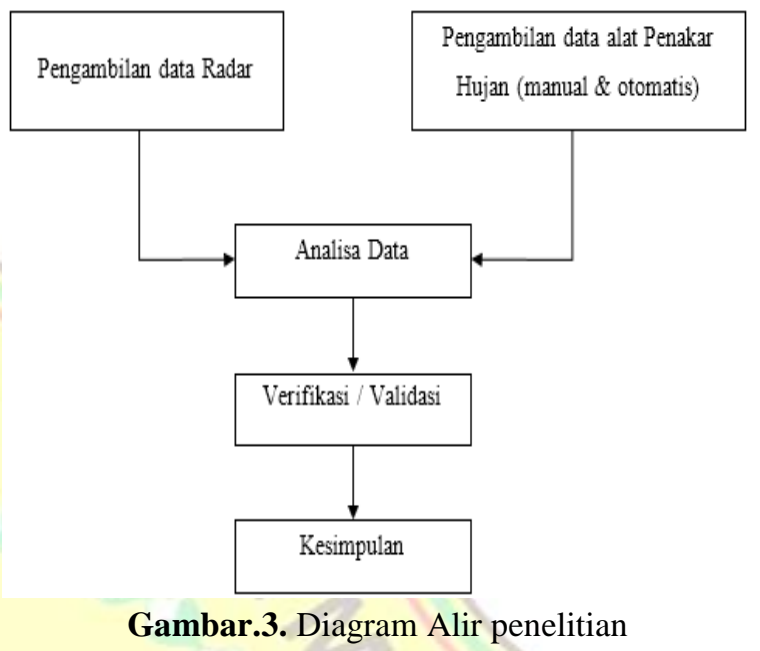

Tabel. 1. Spektrum Warna dan Intensitas Curah Hujan (mm/Jam) [7].

\begin{tabular}{llc}
\hline \multicolumn{1}{c}{ Warna } & \multicolumn{2}{c}{$\begin{array}{c}\text { IntensitasCurahHujan } \\
(\mathbf{m m} / \mathbf{J a m})\end{array}$} \\
& \multicolumn{1}{c}{ Range } & \multicolumn{1}{c}{ Angka } \\
\hline Merah & $>100$ & $100 \mathrm{~mm} / \mathrm{Jam}$ \\
MerahMud & $40-100$ & $70 \mathrm{~mm} / \mathrm{Jam}$ \\
a & $20-40$ & $30 \mathrm{~mm} / \mathrm{Jam}$ \\
Hijau & $10-20$ & $15 \mathrm{mmJam}$ \\
Kuning & 10 & $6 \mathrm{~mm} / \mathrm{Jam}$ \\
BiruMuda & $2-10$ & $1,1 \mathrm{~mm} / \mathrm{Jam}$ \\
BiruTua & $0,2-2$ & $0,2>0,2$ \\
Hitam & $>0,2$ & 0,2 \\
\hline
\end{tabular}

\section{Pengambilan Data Pada Alat Penakar Hujan Manual}

Jika terjadi hujan air akan tertampung pada tabung alat penakar, air yang tertampung tidak akan mengalir dan tidak menguap, setelah itu air diambil dengan menggunakan gelas ukur, dan air itu diamati seberapa banyak air yang mengalir.

\section{Pengambilan Data Pada Alat Penakar Hujan Otomatis}

Alat penakar ini diamati dengan cara melihat garis-garis pada kertas pias, bila terjadi hujan, air hujan akan mengenai tiping bucket pada alat tersebut, dan tiping bucket akan bergerak dan menggoreskan tinta pada kertas pias. 


\section{Analisa Data}

Pengolahan data dalam penelitian ini menggunakan beberapa analisa diantaranya:

1. Analisa Statistik yaitu analisa yang berhubungan dengan perhitungan statistik yang dilakukan dengan persamaan adalah $M A E=\frac{\sum\left|n_{f}-n_{a}\right|}{m}$

Korelasi $=$

$r_{x y z} \frac{n \sum x i y i-\sum x i \sum y i}{\sqrt{n \sum x i^{2}-\left(\sum x i\right)^{2} \cdot n \sum y i^{2}-\left(\sum y i\right)^{2}}}$

$$
\begin{aligned}
& S x_{2}=\frac{\sqrt{\mathrm{n} \cdot \sum \mathrm{x}-\left(x^{2}\right)}}{\mathrm{n} \cdot(\mathrm{n}-1)} \\
& S y_{2}=\frac{\sqrt{\mathrm{n} \cdot \sum \mathrm{x}-\left(y^{2}\right)}}{\mathrm{n} \cdot(\mathrm{n}-1)}
\end{aligned}
$$

Setelah hasil di dapat dari ketiga data di dapat maka dicari $H_{l}$ dan $H_{0}$ dengan rumus:

$H=\frac{S_{\text {besar }}}{S_{\text {kecil }}}$

1. Untuk rata-rata nilai MAE:

$$
\begin{aligned}
\frac{\sum M A E}{n} \times 100 \% & =\frac{1.667}{8} \times 100 \% \\
& =0,208 \%
\end{aligned}
$$

2. Untuk rata-rata nilai Koefisien Korelasi:

$$
\begin{gathered}
\frac{\sum \text { Korelasi }}{n} \times 100 \%=\frac{0,033}{8} \times 100 \% \\
=0,004 \%
\end{gathered}
$$

3. Untuk rata-rata nilai Uji Homogenitas:

$$
\begin{aligned}
\frac{\sum \text { Homogenitas }}{n} & \times 100 \% \\
& =\frac{3,021}{8} \times 100 \% \\
& =0,378 \%
\end{aligned}
$$

2. Analisa Deskriptif adalah analisa yang memberikan gambaran tentang pengolahan data yang telah dibuat dalam bentuk grafik. Analisa tersebut dilakukan setelah analisa diatas dikerjakan terlebih dahulu.

\section{Verifikasi/Validasi}

Memverifikasi/memvalidasinya dengan pengambilan data dalam bentuk Tabel.

Hasil dari verifikasi dan validasi data, selanjutnya akan dibahas secara deskriptif untuk mengetahui keakuratan data citra radar Doppler dalam memprediksi curah hujan di kota Pekanbaru.

\section{HASIL DAN PEMBAHASAN}

\section{Hasil}

Berikut ini menampilkan hasil pengamatan tentang curah hujan pada waktu yang berbeda beda dengan menggunakan hasil dari pencitraan radar dan data alat penakar hujan pada tanggal 21 November - 28 November 2013.

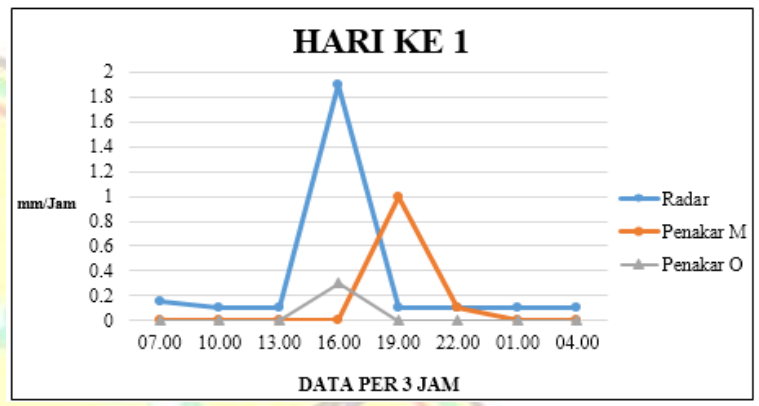

Gambar. 4. Data Radar dan Penakar Hujan pada Hari Pertama

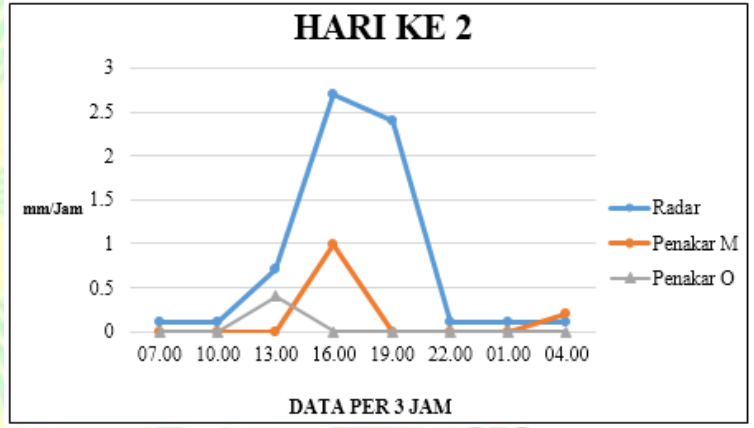

Gambar. 5. Data Radar dan Penakar Hujan pada Hari Kedua

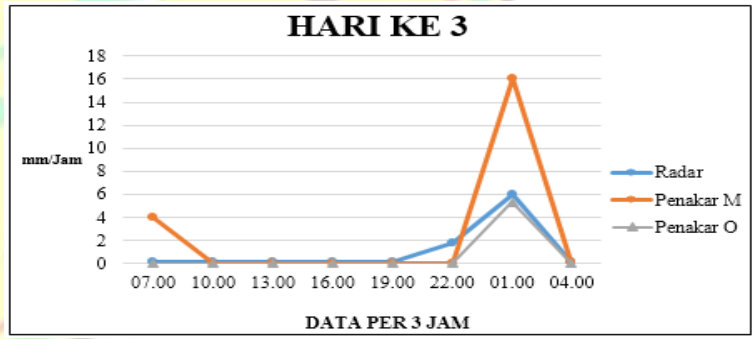

Gambar.6. Data Radar dan Penakar Hujan pada Hari Ketiga

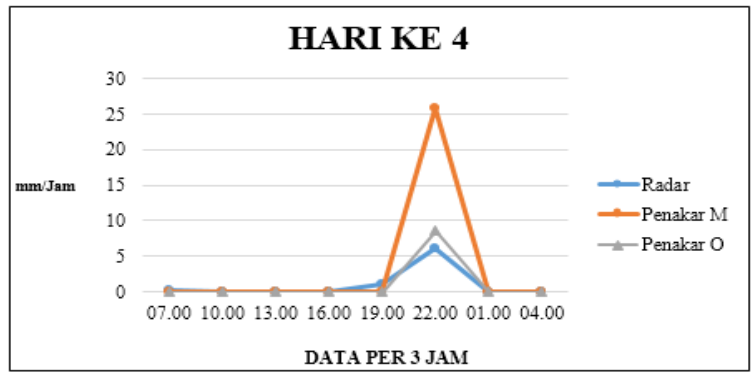

Gambar.7. Data Radar dan Penakar Hujan pada Hari Keempat 


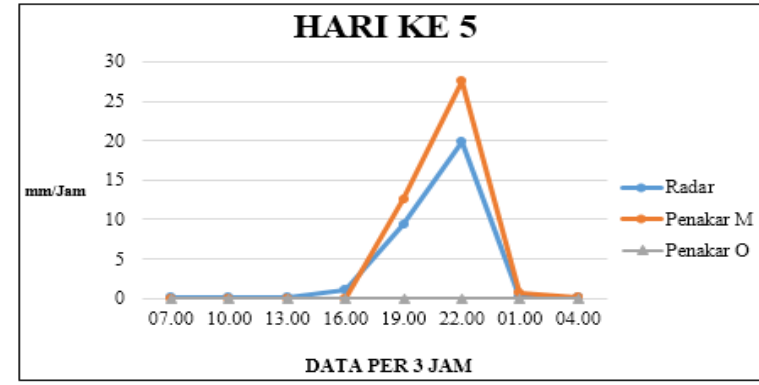

Gambar.8. Data Radar dan Penakar Hujan pada Hari Kelima

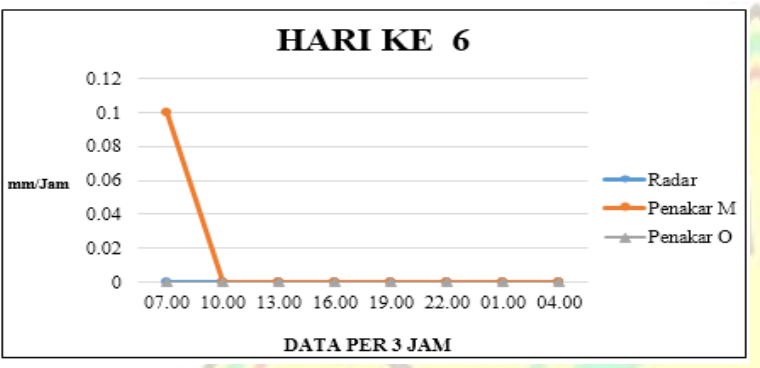

Gambar. 9. Data Radar dan Penakar Hujan pada Hari Keenam

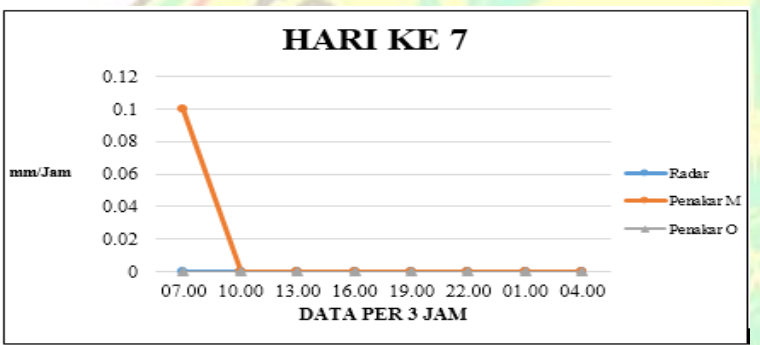

Gambar. 10. Data Radar dan Penakar Hujan pada Hari Ketujuh

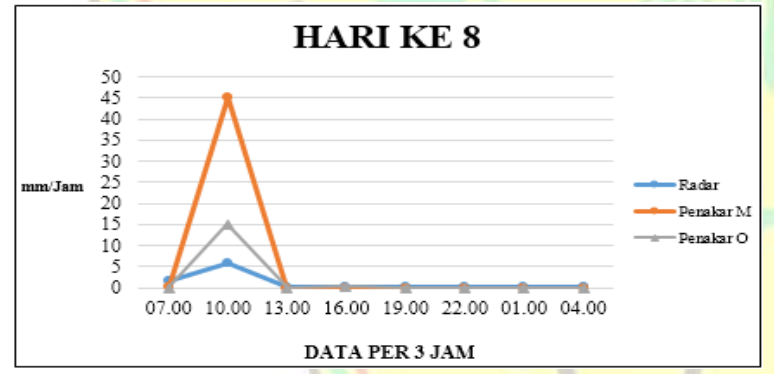

Gambar. 11. Data Radar dan Penakar Hujan pada Hari Kedelapan

\section{November 2013}

Gambar 4 menunjukkan hasil dari pengambilan data radar dan penakar hujan otomatis serta manual pada hari pertama yaitu tanggal 21 November 2013. Data tersebut merupakan data yang telah diperoleh dari ratarata waktu setiap 3 jam dalam sehari.

Dari gambar tersebut terlihat jika data radar memiliki nilai yang lebih tinggi dibandingkan dengan data penakar hujan, baik otomatis maupun manual. Akan tetapi nilai tersebut tidak berada pada waktu yang sama. Untuk data radar bernilai lebih tinggi terletak pada pukul16.00. Sedangkan untuk data penakar hujan otomatis nilai tinggi pada pukul19.00. Dan untuk penakar hujan manual nilai terdapat pada pukul 22.00.

Dengan hasil tersebut, maka dengan pada tanggal 21 November 2013 pencitraan radar mampu memprediksi hujan lebih baik dibandingkan dengan alat penakar hujan otomatis maupun manual. Nilai yang dihasilkan dari data radar lebih tinggi 2 kali lipat dibandingkan data penakar hujan.

\section{November 2013}

Hari kedua yang ditunjukkan pada Gambar 5 , terlihat jika data yang dihasilkan radar lebih tinggi dibandingkan dengan alat penakar hujan otomatis dan manual. Hal tersebut dapat dilihat dari data radar pada pukul 16.00 lebih tinggi dibandingkan dengan data penakar hujan otomatis dan manual. Selain itu data yang dihasilkan dari radar cenderung meningkat dari pukul 10.00, 13.00 dan 16.00. Selanjutnya data tersebut menurun di waktu pukul 22.00 dan stabil hingga 04.00.

Untuk data alat penakar hujan otomatis nilai tertinggi terdapat pada pukul 16.00 juga. Dan untuk penakar manual data juga terdapat pada pukul 16.00 dan 04.00. Akan tetapi, nilai penakar hujan otomatis dan manual tersebut masih berada jauh di bawah nilai data yang dihasilkan oleh radar.

Perubahan nilai radar pada setiap 3 jam tersebut tidak mempengaruhi kemampuan dari citra radar dalam memprediksi curah hujan jika dibandingkan dengan alat penakar hujan. Hal tersebut dapat dilihat pada nilai radar yang lebih tinggi dibandingkan dengan data penakar hujan.

Dengan demikian, berdasarkan hasil tersebut maka pada hari kedua tanggal 22 November 2013. Hasil dari citra radar Doppler memiliki kemampuan yang lebih baik dalam memprediksi curah hujan. Sedangkan dari hasil data tersebut untuk alat penakar hujan baik otomatis maupun manual kurang efektif dalam memprediksi curah hujan. 


\section{November 2013}

Gambar 6 menunjukkan hasil dari data radar dan penakar hujan otimatis serta manual. Dari gambar tersebut terlihat jika pada tanggal 23 November 2013, nilai data radar lebih rendah dibandingkan penakar hujan otomatis. Sedangkan penakar hujan manual lebih rendah dibandingkan dengan data radar. Nilai dari data radar dari pukul 07.00 hingga 19.00 cenderung sama kemudian naik pada pukul 22.00 dan 01.00 kemudian menurun kembali pada pukul 04.00.

Kemudian untuk data penakar hujan manual, nilai cenderung sama hingga pukul 22.00 dan kemudian naik pada pukul 01.00. Nilai kenaikkan pada pukul 01.00 sangat tinggi. Kenaikan nilai tersebut sama dengan naiknya nilai radar pada pukul 01.00. Sedangkan untuk penakar otomatis data hanya terdapat pada pukul 07.00, dan bernilai nol hingga 04.00. Namun data dari penakar hujan manual masih berada di bawah data yang dihasilkan oleh radar.

Lebih tingginya nilai data penakar hujan otimatis hanya terdapat pada pukul 01.00. Sedangkan untuk nilai data radar, sudah mulai naik pada pukul 22.00. Meskipun kenaikan nilai data radar lebih rendah dibandingkan dengan data penakar, radar masih tetap memiliki kelebihan. Kelebihan dari radar tersebut yaitu karena radar mampu terlebih dahulu memprediksi adanya curah hujan.

Kemampuan radar dalam memprediksi hujan terlebih dahulu dibandingkan dengan penakar dapa dilihat pada nilai data pada pukul 22.00. Pada waktu tersebut radar mampu memprediksi curah hujan terlebih dahulu dibandingkan penakar hujan. Dengan demikian pada tanggal 23 November 2013, radar masih tetap memiliki fungsi yang lebih baik dalam memprediksi curah hujan dibandingkan dengan alat penakar hujan.

\section{November 2013}

Gambar 7 merupakkan hasil dari data radar dan penakar hujan otomatis serta manual pada tanggal 24 November 2013. Pada gambar tersebut menunjukkan hasil yang hampir sama dengan data pada tanggal 23 November 2013.
Dari data gambar tersebut terlihat jika nilai penakar otomatis dan manual jauh lebih tinggi dibandingkan dengan data radar. Akan tetapi pada data radar menunjukkan jika radar mampu memprediksi akan adanya hujan pada pukul19.00. Dengan hal tersebut maka radar meskipun data bernilai kecil, namun radar mampu memprediksi terlebih dahulu akan adanya curah hujan.

Dengan tingginya data penakar pada tanggal 24 November 2013 tidak mempengaruhi kelebihan dari radar. Yaitu kemampuan radar yang dapat memprediksi curah hujan terlebih dahulu dibandingkan dengan penakar hujan otomatis dan manual.

\section{November 2013}

Data radar yang dihasilkan pada tanggal 25 November juga lebih tinggi dibandingkan dengan data penakar hujan otomatis. Dan untuk penakar hujan manual data bernilai nol. Hal tersebut menandakan jika penakar hujan otomatis lebih bagus dibandingkan dengan penakar hujan manual.

Tingginya data nilai penakar hujan otomatis tidak mengurangi kelebihan radar yang mampu memprediksi curah hujan terlebih dahulu dibandingkan dengan penakar hujan. Hal tersebut dapat dilihat pada Gambar 8 yang menunjukkan jika pada pukul 16.00 radar sudah memiliki nilai yang lebih tinggi dibandingkan dengan data penakar hujan. Sehingga radar lebih cepat memprediksi hujan dibandingkan dengan alat penakar hujan.

Kemudian pada pukul 19.00 radar juga sudah mendeteksi akan adanya hujan. Sedangkan untuk penakar hanya mampu mendeteksi pada pukul 22.00. Maka dari itu, berdasarkan data tersebut radar masih memiliki kelebihan dibandingkan dengan penakar hujan.

\section{November 2013}

Gambar 9 menunjukkan hasil dari data radar dan penakar hujan pada tanggal 26 November 2013.

Dari gambar tersebut terlihat jika nilai dari masing-masing alat yaitu radar dan penakar otomatis maupun manual sangat kecil. Untuk 
penakar hujan otomatis nilai hanya terdapat pada pukul 07.00. Dan untuk penakar hujan manual data bernilai nol. Begitu juga untuk data radar sama sekali tidak terdapat nilai disemua waktu. Hal tersebut disebabkan karena pada tanggal tersebut terjadi hujan, sehingga alat penakar maupun radar tidak dapat berfungsi dengan baik. Nilai yang ditunjukkan pada radar bernilai nol, dikarenakan terjadi hujan dan baterai pada radar habis. Sehingga pada tanggal 26 November 2013 radar tidak dapat berfungsi sama sekali.

\section{November 2013}

Pada tanggal 27 November juga terjadi hujan sehingga data yang dihasilkan sama dengan data pada tanggal 26 November 2013. Data tersebut dapat dilihat pada Gambar 10 yang menunjukkan nilai data radar dan penakar hujan otomatis serta manual pada tanggal 27 November 2013. Dimana pada data tersebut terlihat, jika nilai dari ketiga alat tersebut sangat rendah, bahkan bernilai nol.

Dan untuk data radar rendah dikarenakan radar pada tanggal tersebut mati. Penyebab matinya radar tersebut yaitu karena baterai didalam radar habis. Sehingga dengan hal tersebut meyebabkan radar tidak berfungsi.

\section{November 2013}

Tanggal 28 November 2013 merupakan hari terakhir pengambilan data pada radar dan penakar hujan. Data dari radar dan penakar hujan otomatis serta manual tersebut dapat dilihat pada Gambar 11. Gambar tersebut menunjukkan hasil data pada tanggal 28 November 2013. Dari gambar tersebut nilai radar lebih rendah dibandingkan dengan data penakar hujan otomatis dan manual. Dan kedua data dari penakar hujan jauh lebih tinggi dibandingkan dengan data radar.Akan tetapi, tingginya kedua data alat penakar hujan tersebut terdapat pukul 10.00. Dan untuk data radar, nilai mulai terdapat pada pukul 07.00 dan 10.00 .

Sehingga dengan demikian radar mampu memprediksi terlebih dahulu adanya curah hujan dibandingkan dengan penakar.Dengan hasil tersebut maka dapat dikatakan jika hasil pengukuran antara radar dan alat penakar hujan lebih baik data yang diperoleh dari radar dibanding alat penakar hujan. Hal tersebut dikarenakan radar mampu memprediksi hujan terlebih dahulu dibandingkan dengan penakar.

\section{Pembahasan}

Hasil yang telah diperoleh di atas merupakan hasil rata-rata dari waktu setiap 3 jam dalam 1 hari. Dimana data dari alat penakar hujan terdapat dua jenis yaitu otomatis dan manual. Penakar hujan manual merupakan hubungan antara air yang tertampung pada gelas ukur dengan pengamat. Sementara data yang diperoleh oleh radar merupakan hubungan ketebalan awan dengan jumlah curah hujan. Hubungan antara suhu puncak awan dengan jumlah curah hujan ditunjukkan dengan pola warna. Pola warna yang terbentuk menjelaskan adanya perbedaan suhu yang satu dengan suhu yang lainnya.

Dari perhitungan dengan menggunakan data hasil pencitraan dari radar dan alat penakar hujan selama 8 hari, maka diperoleh nilai dari uji MAE, Korelasi dan homogenitas sebagai beriktut:

\section{Uji Mean Absolute Error (MAE)}

Hasil perkiraan data yang akurat adalah perkiraan yang bisa meminimalkan kesalahan perkiraan. Karena itu dalam menghitung kesalahan meramal digunakan MAE. MAE merupakan hasil nilai mutlak dari selisih antara nilai keluaran model dengan data sebenarnya. Hasil MAE yang didapat pada Tabel. 2.

Tabel. 2. Hasil Perhitungan Uji MAE

\begin{tabular}{ccc}
\hline No & Tanggal & MAE \\
\hline 1 & $21 / 11 / 2013$ & 0.158 \\
2 & $22 / 11 / 2013$ & 0.463 \\
3 & $23 / 11 / 2013$ & 1.516 \\
4 & $24 / 11 / 2013$ & 3.343 \\
5 & $25 / 11 / 2013$ & 1.305 \\
6 & $26 / 11 / 2013$ & 0.013 \\
7 & $27 / 11 / 2013$ & 0.013 \\
8 & $28 / 11 / 2013$ & 6.525 \\
\hline \multicolumn{2}{c}{}
\end{tabular}

Dari hasil pengamatan nilai MAE diatas maka diperoleh kesimpulan, bahwa nilai yang dihasilkan benar, hal tersebut dikarenakan nilai yang diperoleh lebih kecil dari 5 . 


\section{Uji Koefisien Korelasi}

Untuk mencari hubungan antara dua variabel atau lebih dilakukan dengan menghitung korelasi antar variabel yang akan dicari hubungannya. Rumus Koefisien Korelasi dapat dihitung dengan persamaan (3.2).

Hasil perhitungan dengan menggunakan persamaan 2.2, dapat dilihat pada Tabel 3 .

Tabel. 3. Hasil Perhitungan Uji Korelasi

\begin{tabular}{ccc}
\hline No & Tanggal & Korelasi \\
\hline 1 & $21 / 11 / 2013$ & 0.121 \\
2 & $22 / 11 / 2013$ & 0.087 \\
3 & $23 / 11 / 2013$ & 0.018 \\
4 & $24 / 11 / 2013$ & 0.018 \\
5 & $25 / 11 / 2013$ & 0.006 \\
6 & $26 / 11 / 2013$ & 0 \\
7 & $27 / 11 / 2013$ & 0 \\
8 & $28 / 11 / 2013$ & 0.015 \\
\hline & Rata-rata & 0.033 \\
\hline
\end{tabular}

Dari data diatas, maka ditarik kesimpulan jika berdasarkan hasil pengamatan yang diperoleh, maka hubungan pada setiap pengamatan adalah lemah dan berbanding lurus yang dikarenakan memiliki nilai positif(+).

\section{Uji Homogenitas}

Hasil dari perhitungan Uji Homogenitas dengan menggunakan rumus uji homogenitas, hasil yang didapat pada Tabel 4 .

Tabel. 4. Hasil Perhitungan Uji Homogenitas

\begin{tabular}{ccc}
\hline No & Tanggal & Uji Homogenitas \\
\hline 1 & $21 / 11 / 2013$ & 1.21 \\
2 & $22 / 11 / 2013$ & 2.17 \\
3 & $23 / 11 / 2013$ & 3.4 \\
4 & $24 / 11 / 2013$ & 9.26 \\
5 & $25 / 11 / 2013$ & 0.61 \\
6 & $26 / 11 / 2013$ & 0 \\
7 & $27 / 11 / 2013$ & 0 \\
8 & $28 / 11 / 2013$ & 7.53 \\
& Rata-rata & 3.021 \\
\hline
\end{tabular}

Dari pengamatan, maka dapat ditarik kesimpulan bahwa tingkat homogenitas yang diperoleh rata-rata selama 8 hari yaitu 3,021, data tersebut tidak homogen karena nilainya lebih dari 0,05 .

\section{Verifikasi Data}

Verifikasi data dilakukan untuk memeriksa kebenaran data yang diteliti benar atau tidak. Hasil verifikasi ini memberikan nilai perbandingan yang pasti mengenai hasil prakiraan dengan kondisi sebenarnya, pernyataan tersebut dinyatakan dalam nilai kebenaran. Pernyataan yang dianggap benar dimana kondisi sebenarnya sesuai dengan hasil prakiraan memberikan informasi lebih sebagai tanda peringatan walaupun tidak sepenuhnya terjadi pada kondisi di lapangan dengan asumsi prakiraan tetap pada keadaan sebenarnya.

Selain itu prakiraan dianggap salah ketika kondisi sebenarnya secara garis besar menggambarkan hasil prakiraan, tetapi terjadi kondisi cuaca tiba - tiba yang sangat berbeda dengan hasil asumsi hasil prakiraan. Sedangkan rumus yang digunakan berupa MAE (persamaan 3.1), nilai koefisien korelasi (persamaan 3.2) dan nilai Uji Homogenitas (persamaan 3.3 dan 3.4). Tahap pertama yaitu berupa data alat penakar hujan dan dikelompokkan menjadi delapan bagian,dimana alat penakar hujan diamati setiap 3 jam selama 8 hari dengan rata-rata dari uji MAE, Korelasi dan Homogenitas, maka nilai kebenarannya adalah:

Persentase hujan yang sering terjadi pada Nilai MAE yang diperoleh rata-rata 0,208 \%. Jika semakin kecil nilai MAE maka nilai yang dihasilkan benar. Untuk nilai tingkat homogenitas yang diperoleh rata-rata $0,378 \%$ maka $\mathrm{H}_{0}$ (hipotesis nol) diterima dan $\mathrm{H}_{1}$ (hipotesis satu) homogen, karena nilai $\mathrm{H}_{0}$ dan nilai $\mathrm{H}_{1}$ lebih kecil dari 0,5. Kemudian dari perhitungan nilai koefisien korelasi antara radar dan alat penakar hujan sebesar $0,004 \%$, maka hubungan antara radar dengan alat penakar hujan sangat lemah karena nilainya berada antara $-0,5 \leq$ $\mathrm{r}(\mathrm{x}, \mathrm{y}, \mathrm{z}) \leq-1$.

\section{KESIMPULAN}

Dari hasil penelitian mengenai citra radar doppler maka dapat diambil beberapa kesimpulan sebagai berikut:

1. Berdasarkan dari hasil uji Statistik. Seperti: uji MAE, Koefisien Korelasi, dan Uji Homogenitas, maka radar mampu 
memprediksi curah hujan di Pekanbaru dengan benar.

2. Dari hasi uji homogenitas nilai $M A E$ adalah $0,208 \%$, karena nilai tersebut berada di antara -1 sampai 1 maka data yang dihasilkan memiliki perkiraan kesalahan yang minimal.

3. Nilai Koefisien Korelasi rata-rata berada antara $-0,5 \leq \mathrm{r}(\mathrm{x}, \mathrm{y}, \mathrm{z}) \leq-1$, maka tingkat korelasinya lemah dan berbanding lurus.

4. Dan nilai rata-rata dari uji homogenitas lebih besar dari nilai yang diharapkan yaitu 0,05. Maka data radar dan data dari alat penakar hujan tidak homogen.

\section{DAFTAR PUSTAKA}

As-syakur A Rahman. 2011. Pola Spasial Hubungan Curah Hujan dengan ENSO dan IOD di Indonesia - Observasi Menggunakan Data TRMM $3 B 43$. Denpasar Bali. Universitas Udayana.

Sumiyati Sri, Budi Warsito. 2007. Prediksi Curah Hujan Kota Semarang Dengan Feedforward Neural Network Menggunakan Algoritma Quasi Newton BFGS Dan Levenberg-Marquardt. Jurnal PRESIPITASI Vol. 3 No.2 September 2007, ISSN 1907-187X.

Rouw Aser. 2008. Analisis Dampak Keragaman Curah Hujan Terhadap Kinerja Produksi Padi Sawah (Studi kasus di Kabupaten Merauke, Papua).Papua Barat. Jurnal Pengkajian dan Pengembangan Teknologi Pertanian Vol. 11, No.2, Juli 2008: 145-154.

Yulianto Tony, Rahmat Gernowo.2010. Fenomena Perubahan Iklim dan Karakteristik Curah Hujan Ekstrim di DKI Jakarta. Semarang. FMIPA Universitas Diponegoro Semarang.

Achmadi Sahid, Sumardi, Iwan Setiawan. 2009.

Penakar Curah Hujan Otomatis Dengan Data Logger Sd/Mmc Berbasis SMS (Short Message Service). Semarang. Jurusan Teknik Elektro Fakultas Teknik Universitas Diponegoro Semarang. http://www.spc.noaa.gov/faq/tornado/doppler.ht $\underline{\mathrm{m}}$

Kaukab Muhammad. 2008. Rancang Bangun Simulasi Radar. Jakarta. Univeritas Indonesia.

Tjasyono bayong. 2004. Klimatologi. Bandung. Institut Teknologi Bandung.

Girsang Febrina. 2008. Analisis Curah Hujan Untuk Pendugaan Debit Puncak Dengan Metode Rasional Pada DAS Belawan Kabupaten Deli Serdang. Medan. Fakultas Pertanian Universitas Sumatera Utara.

Masruroh Lailatul. 2013. Analisis Curah Hujan Harian Maksimum Dan Ekstrim Di Kabupaten Bogor. Bogor. Institut Pertanian Bogor.

Paramita Putri Sea, Sutikno. 2010. Klasifikasi Sifat Curah Hujan Berdasarkan Indikator Enso (El-Nino Southern Scillation) $\mathrm{Di}$ Kabupaten Ngawi Denganmenggunakan Metode Klasifikasi Pohon. Surabaya. Jurusan Statistika FMIPA-ITS.

Hanifah Annie, Endarwin. 2010. Analisis Intensitas Curah Hujan Wilayah Bandung Padaawal2010. Bandung. Stasiun Geofisika Kelas 1 Bandung, Jl.Cemara 66 Bandung.

Gunawan Putu Nopa. 2013. Radar Dan Navigasi. Makasar. Jurusan Teknik Elektro Fakultas Teknik Universitas Hasanuddin

Gustomo Fery, Suwadi. 2013. Analisa Penggunaan Sinyal Radar Bentuk Pulsa dan Gelombang Kontinyu untuk Target Bergerak dengan Model Clutter Terdistribusi Rayleigh. Surabaya. Jurnal Teknik PomitS Vol. 2, No. 2, (2013) ISSN: 2337-3539 (2301-9271 Print).

Gustina Mona Hakim. 2012. Analisa sebaran awan untuk menentukan Prediksi curah hujan di kota pekanbaru Berdasarkan data penginderaan jarak jauh. Pekanbaru. Skripsi Universitas Riau. 